\title{
Investigating and Analyzing ESP College Students’ Errors in Using Synonyms
}

\author{
Edhah Numan Khazaal ${ }^{1}$ \\ ${ }^{1}$ Department of International Economic Relations, College of Political Sciences, University of Al-Nahrain, Iraq \\ Correspondence: Edhah Numan Khazaal, Department of International Economic Relations, College of Political \\ Sciences, University of Al-Nahrain, Iraq. E-mail: Khazaalethah12@gmail.com
}

Received: July 9, 2019 Accepted: July 30, 2019 Online Published: September 6, 2019

doi:10.5539/ijel.v9n5p328 URL: https://doi.org/10.5539/ijel.v9n5p328

\begin{abstract}
This study aims to investigate and analyze the errors of English for specific purposes of college students in using synonyms. It also discovers the difficulties that faced ESP students in using synonyms. A descriptive-analytical method was used in this study. The population of the study were (60) ESP college students from the college of Political Sciences at Al-Nahrain University, in the academic year 2018-2019. The sample consists of (50) ESP for college students, which were chosen randomly. Data for the study were collected from the written test which consisted of different five questions and each question contains five items, so the total items were 25 . The findings of the study showed the importance of error analysis for the learners and teachers; it can provide a good methodology for investigating learners' errors in English. The study discovered that the most occurred errors are due to their limited knowledge of acquisition of vocabulary especially for learners who study English for specific purposes. The insufficient of vocabulary knowledge causes many difficulties for learners in choosing the correct synonyms and, hence, they committed errors which prevent their advance in learning natural English. Finally, the study concludes with some recommendations for further research.
\end{abstract}

Keywords: errors analyses, ESP, synonyms

\section{Introduction}

English is an international language. It's full of words and it's considered as the richest of all languages in synonyms. English has inherited and borrowed many words from other languages and create new words to represent new ideas.

One of the main elements that English foreign language learners need is vocabulary. It is the knowledge of knowing the meaning of the word. ( Hatch \& Brown, 1995, p. 1).Having a good vocabulary is really important to develop learners' capability in using English skills, so when you learn new words, you have to think about their synonyms. When we talk about vocabulary, we usually mean words, as much as you learn and know words, the more clearly, obviously and powerfully you will think... and the more ideas you will keep in your mind. (Wilfred Funk, 2015)

Some educators believe that vocabulary is more important for the ESL students than grammar, as acquiring many words can help learners to use the language correctly. Cameron (1994, p. 34) confirmed that the basic level category in learning a language seem to be words.

Synonyms are defined as words or phrases that mean the same meaning as another words or phrases in the same language. There are many words in English which are similar in meaning but different in their forms, these words considered problematic for foreign language learners in recognizing how to choose them in their correct position.

The researcher in his study focuses on ESP students 'errors in using synonyms. Synonyms are decisive to the mastery of English at all levels of learning. They are words that substitute in a context for other words.

Errors, committed by the second of foreign language learners, are an important aspect of language learning. By making errors, learners can develop their skills through getting the correct forms from their teacher. So, errors and their analysis are advantageous for both the learners and teachers.

Most English second language (ESL) teachers agree that the errors committed by students in writing aren't 
permitted, while there is another idea which said that the more mistakes student make, the more he will learn.

Committing errors reflect the learner internal structure and the amount of knowledge a learner has of certain a language (Selinker, 1972).

\subsection{The Problem}

Acquiring adequate vocabulary is essential for learning any foreign language because without sufficient vocabulary, learners will be unable to use the structures and functions of that language (Rivers \& Nunan, 1991).

Learning the meaning of a word is the most practical way to build vocabulary.

Due to (Afghari \& Khayatan, 2017, p. 122), "learning new vocabularies, which is one of the most important sub-skills of the language, seems to be a complicated process involving a variety of sub-processes and tasks demanding more elaboration to be internalized".

Synonyms are those words that have a similar or related meaning, to another word. English has a lot of words that are considered synonymous and acquiring those words are very important skill in learning English as a second or a foreign language.

According to Read (2000, p. 1), "Words are the basic building blocks of language, the units of meaning from which the larger structures such as sentences, paragraphs, and whole texts are formed".

ESL learners mostly used synonyms to avoid repeating similar words in their speaking or writing English. They were confused by using words that are similar in meaning than words that do not have close semantic relations (Higa, 1963).

Synonym learning is not a simple task, because learners can't use the real word unless they know their meaning, learner should be aware in choosing the suitable word, because such word don't carry the same meaning as the learner meant, so they need to have enough knowledge with many words, and know how and when to use them correctly.

One of the problems that faced the English learners is contributed to the lack and limited of their knowledge in using vocabularies and this is due to many reasons such as the low frequency in reading, the low awareness in expanding new vocabularies, which would lead to committed errors in using (lexical) in speaking or writing skills . (Normazidah, Koo, \& Hazita, 2012).

In recent years, it has been noted that the production and analysis of synonymous errors becomes a common concern for ESL/EFL learners. This may indicate that acquiring synonymy is an important skill in second language (L2) contexts (Martin, 1984; Hatch \& Brown, 1995; Yeh et al., 2007; Liu, 2013; Liu \& Zhong, 2014).

To investigate the problem, researchers should examine the types of errors that ESL learners' committed. According to Corder (1974) systematically analyzing errors made by language learners can tell us about the learners' mastering of second language.

The errors committed by EFL/ESL learners in general related to an adequate knowledge in English vocabularies, which caused by many reasons such as the low frequency in reading, the low awareness in expanding new vocabularies, and for Iraqi students in particular, errors might committed due to many reasons such as; the lack of acquiring vocabulary, the traditional methods that are used in teaching English in Iraqis colleges' especially in writing skill.

The teacher main task is to correct students' errors. They try to find the committed errors and correct them in order to help their students to progress in their English language development.

Many teachers try to make emphasizes on teaching grammar over vocabulary although learning vocabulary and other lexical units are at the heart of learning and communication.

ESL Teachers, generally, are the ones who suffer from such a problem. Their main task is to teach their students how to think and to use a foreign language correctly and as the native users do.

\subsection{The Significance}

Analyzing errors is very crucial for second language teaching and learning. Learner errors are "windows into the language learners mind" (Saville Troike, 2006, p. 39).

Ellis (1985, pp. 51-54) asserted that the most significant contribution of error analysis lies in its success in elevating the status of errors from undesirability to that of a guide.

English language is full of words and phrases that have the same as another lexeme in the same language, we call them synonyms. The use of synonyms can help learners to make their writing brighter and to create an interesting 
picture in the mind of the reader.

Second language learners make unsystematic performance errors in using synonyms in their correct position, so analyzing error process through error data collection, classification, explanation and evaluation is a good step for investigation .(Ellis, 1994)

In order to develop second language learners' proficiency, they need to acquire enough knowledge of new vocabulary by getting two synonyms for each word and kept them in their mind. Synonyms considered as an operative key for learning English. It plays an important part in our daily speech.

Words can be synonymous when meant in certain recognition, even if they are not synonymous in all of their senses. Using synonyms in your speech and writing gives a good impression that your mind is full of word which makes your communication more colorful. Moreover, synonyms prevent you from repeating the same words many times, which makes your speech boring and useless.

Teaching synonyms is such an important skill for ESL learners. When students learn how to use them perfectly, they'll be able to understand what they hear and read even better. They'll also enlarge their vocabulary with new different words, so they aren't using the same ones in their writing over and over.

Learners with stronger vocabulary knowledge can learn odd thought better than can those with weaker vocabulary knowledge (Baumann, Kame'Enui, \& Ash, 2003). Having the same statement with many different words will make your speech, or writing, more creative.

\subsection{Objectives of the Study}

The objectives of the study are as follow:

1) To investigate and analyze the errors committed by ESP college students in using synonyms.

2) To determine the causes and difficulties of these errors.

\subsection{The Hypothesizes}

The study hypothesized the followings:

1) Do ESP of college students committed errors and have difficulties in using English synonyms correctly?

2) What types of errors the ESP college students have when they use English synonyms?

\subsection{Limitations of the Study}

The study is limited to the ESP second year students in the college of Political Sciences at Al-Nahrain University, Iraq, during the academic year 2018/2019.

\section{Literature Review and Related Studies}

\subsection{What Are Synonyms?}

The meaning of the word synonym comes from the Greek syn, meaning with, and onoma, meaning "name and means the same name" (Crystal, 1995, p. 164). It's a phenomenon in which the words that sound different (different in pronunciation) but have the same or identical meaning as another word or phrase.

Synonyms are two words that can be interchanged in a context are said to be synonymous relative to that context, they occur in a language in different contexts, such as formal and informal language (Richard Nordquist, 2019).

Synonyms are words or phrases that have the same meaning or a very similar meaning in the same language. The words "big" and "large" are synonyms. They are used to enhance learners" capability in using kinds of words in their speech or writing and allow you to avoid repetition (Cambridge Advanced Learner's Dictionary, 2019).

The word synonymy is used in semantics to refer to a major type of sense relation between lexical items. It is the relationship between two words that have the same sense. Lyons (1981, p. 148) states that synonymy is a linguistic term that refers to lexical items that share the same, or comparable meanings.

English is a language with such a huge vocabulary; many synonyms are very useful, because they can display different variance of the same understanding. They can be presented and used in all English parts of speech.

We use synonyms constantly in our speech and in writing. They are regular and important parts of everyday language that we use almost without thinking. Higa (1963) found that learning pairs of synonyms is difficult and it takes time more than learning pairs of unrelated words.

Learning words with recognized synonyms may be easier than learning words without recognized synonyms, because learners may be able to transfer their knowledge of syntax and collocation from recognized synonyms to 
less frequent synonyms (Webb, 2007, p. 121).

\subsubsection{The Importance of Learning Synonyms}

The use of synonyms can be helpful for the followings:

1) To spice up learners' writing and make it livelier.

2) To advance learners' vocabulary.

3) To create a more intriguing image in the mind of the reader.

4) To encourage learners to think of other ways to say the same old thing.

5) To help learners to impress someone in your writing or speaking.

6) It gives learners a vocabulary that prevents swearing and vulgarity (Hardin, 2014).

\subsubsection{The Benefits of Using Synonyms}

The benefits of using synonyms can be concluded as the following:

1) It makes text much more captivating.

2) It helps to avoid dull text.

3) It Improves communication between you and others.

4) It helps to provide an image in the mind of the reader.

5) It helps to avoid boring and repetitive text. (Enago Academy, 2019)

\subsubsection{Errors Analysis}

Error Analysis is one of the Applied Linguistics branches, which was established in the 1960s by Stephen Pit Corder and colleagues.

Many researcher in the late 1960s and early 1970s, pointed out that there is a need to look for errors committed by second language learners and they found that these errors are not casual mistakes but evidence of rule-governed behavior and the learner's errors cannot possibly be traced to their native language" (Dulay, Burt, \& Krashen, 1982, p. 140). Brown (1980, p. 166) defines error analysis as

“...the processes to observe, analyze, and classify the deviations of the rules of the second language and then to reveal the systems operated by learner."

Error analysis is a very important area and has several implications for learning and teaching English as a foreign or second language.

Taylor (1997, p. 3) states that 'error analysis is the study and evaluation of doubt in extent'.

Errors are advised in order to find out something about the learning process and about the strategies employed by human beings learning another language. It provides a deep insight for understanding of the process of language learning. (Lungu, 2003, p.323)

Falk (1978, p. 360) states that "the study of errors made by foreign language learners reveals much about the process of language learning and the factors that affect this process. One of the main donating of linguistics to the field of foreign language learning is analyzing errors."

Error Analysis is still an integral part of research in EFL studies, because through identifying errors we can measure the learners' performance in any foreign language. The EFL learners' errors are "systematic and reasoned" (Reid, 1993, p. 35).

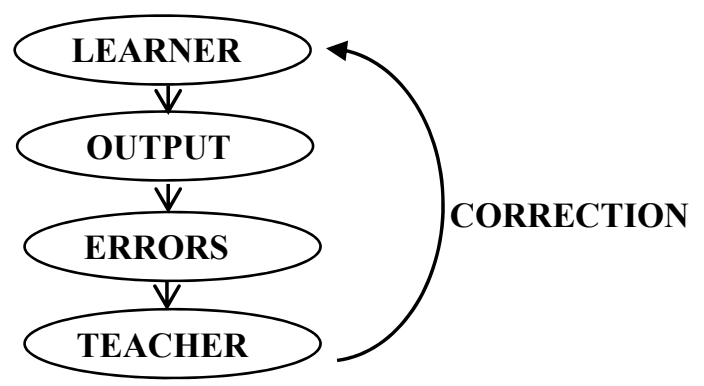

Figure 1. Errors correction process adopted from (Rod Ellis, 1994) 


\subsubsection{The Classification of Errors}

The types of error are classified according to Corder (1974) into four categories, they are:

1) Omission of some required element;

2) Addition of some unnecessary or incorrect element;

3) Selection of an incorrect element; and

4) Ordering of the elements.

2.1.5 Steps for Error Analysis

According to Ellis (1994, p. 48) error analyses are carried out in four consecutive stages. These stages are:

1) Collection of a sample of learner language

2) Identification of errors

3) Description of errors

4) Explanation of errors

5) Evaluation of errors.

\subsection{Previous Studies}

The researcher found many studies that are interested in investigating and analyzing the students' errors and problems in English synonyms.

In Abdalla (2017), he tries in his study to analyze and evaluate EFL learners' errors in using synonyms. He chooses 25 students from College of Languages and College of Education of third year. A descriptive-analytical method and questionnaire were used in his test. The result of his study showed that the students of College of Languages are better in acquisition of synonyms than students of College of Education. The researcher comes to one of the most important result that students of English understand synonyms and they are able to use them correctly.

In Mohammed (2014), he aimed in his study to find out the errors made by EFL learners in choosing synonyms. He tried to discover the most problematic area which faced EFL students in understanding English synonyms. The researcher used a descriptive analytical method by using questionnaire for EFL teachers and a diagnostic test for EFL students.

The researcher reached to the conclusion for the reasons behind errors made by EFL learners in English synonyms. It is caused to the weak syllabuses taught at secondary level and the lack of knowledge of vocabulary items, moreover it is related to the difference between English and Arabic language which confused the students.

\section{Methodology}

\subsection{Study Design}

A descriptive analytical method was used by the researcher to carry out the study, which was conducted for 50 ESP college students.

\subsection{Population and Sample of the Study}

The population of the study was (60) ESP of college students of four departments in the college of Political Sciences at Al- Nahrain University for the academic year 2018-2019

The sample consists of (50) ESP college students in the second year, their age ranged between 19-22 years. All the participants were studying English for Specific Purposes and had the same Text book which was recommended by the Iraqi Ministry of Higher Studies and Scientific Research.

\subsection{The Instrument}

In this study, two types of instruments are used to gather the required data and information from the subject of this study.

\subsubsection{A Written Test for the Students}

The test aimed to investigating the errors made by ESP for college students in using English synonymy, and analyzing these errors.

3.3.2 A Questionnaire for the Teachers

The aim of the questionnaire used in this research was to find out about the teachers' idea about the errors 
committed by ESP college students in using synonyms. The questionnaire consists of 10 items, each item has five points scale, (strongly agree, agree, neutral, disagree and strongly disagree) to show the expected responses from participants. The questionnaire papers send to 20 tutors in the field of English language. The papers were collected for analysis and evaluation. The teachers' questionnaire was administered by the researcher herself. See Appendix (A).

\subsection{The Procedures}

The researcher adapted his test which consisted of five different questions which are designed to investigate the students' knowledge of English synonyms. The test consists of 25 items each question with 5 items. It was designed to cover the different levels of English synonymous such as adjectives, nouns, verbs, adverbs and phrasal verbs. The results of each question are collected and analyzed by calculating the frequency and percentage of the correct and incorrect answers.

\subsection{Validity of the Test}

The test was judged by two experts in the field of English to ensure the validity of the test. Due to the test's evaluation, it was found that the test was valid in both face and content validity. The test validity was 0.92 .

\subsection{Reliability of the Test}

In order to measure the reliability of the test, the researcher used the split half method, as the items of the test were divided into two halves to calculate the correlation between the two sets of scores of the two halves. The reliability obtained was 0.85 . This indicated that the test was reliable.

\subsection{Scoring}

The results of each question are analyzed by calculating the frequency and percentage of the correct and incorrect answers. The test was scored as correct or incorrect because all items allowed for only one clear answer, the un answered items were counted as in correct. The total score for the test was 25 items.

\section{Results and Discussions}

\subsection{Data Analysis}

The research attempts to analyses the data that gained from the students' written test in order to analyze the ESP students' errors in using synonymous.

The procedure of analyzing the error was taken in accordance with the following steps: Data collection, Identification of errors, Classification of errors into error types, the error count.

Table 1. Distribution of students' synonymous errors in the test of question 1

\begin{tabular}{llllllll}
\hline & & Correct & \multicolumn{3}{c}{ Incorrect } & \multicolumn{2}{c}{ Total number } \\
\cline { 3 - 8 } No. & words & Freq. & Per.\% & Freq. & Per.\% & Freq. & Per.\% \\
\hline 1 & bright & 16 & 64.0 & 9 & 36.0 & 25 & $100 \%$ \\
2 & heavy & 18 & 72.0 & 7 & 28.0 & 25 & $100 \%$ \\
3 & happy & 19 & 76.0 & 6 & 24.0 & 25 & $100 \%$ \\
4 & lawful & 6 & 24.0 & 19 & 76.0 & 25 & $100 \%$ \\
5 & tiny & 13 & 52.0 & 12 & 48.0 & 25 & $100 \%$ \\
Total & & 15.8 & 63.20 & 9.2 & 36.60 & 50 & $100 \%$ \\
\hline
\end{tabular}

The table shows the students' responses in finding the suitable synonym for each word fin the first question of the test which represents the use of adjectives in exercise 1. The students response in the words (happy and heavy) have higher percentage $(19,76.0 \%)$ and $(18,72.0 \%)$, this is due to the fact that these words are very easy and familiar to the students, so the errors committed is very low, while (bright and tiny) with percentage (16, $64.0 \%$ and $13,52.0 \%$ ) because they are not common words for them, while (lawful) with low percentage (6, $24.0 \%$ ) because this word is unfamiliar and seems difficult to the students. 
Table 2. Distribution of students' synonymous errors in the test of question 2

\begin{tabular}{llllllll}
\hline & & Correct & \multicolumn{3}{c}{ Incorrect } & \multicolumn{2}{c}{ Total number } \\
\cline { 3 - 8 } No. & words & Freq. & Per.\% & Freq. & Per.\% & Freq. & Per.\% \\
\hline $\mathbf{1}$ & target & 20 & 80.0 & 5 & 20.0 & 25 & $100 \%$ \\
2 & assistance & 9 & 36.0 & 9 & 64.0 & 25 & $100 \%$ \\
3 & fault & 20 & 80.0 & 5 & 20.0 & 25 & $100 \%$ \\
4 & advantage & 15 & 60.0 & 10 & 40.0 & 25 & $100 \%$ \\
5 & agenda & 8 & 33.0 & 17 & 68.0 & 25 & $100 \%$ \\
Total & & 15.8 & 62.41 & 9.5 & 37.61 & 50 & $100 \%$ \\
\hline
\end{tabular}

The presented table shows the students' responses in answering question two by matching the nouns that have a similar meaning it was found that the words (target, fault) with high percentage $(20,80.0 \%)$ because the students are familiar with these synonyms that represent nouns, while the words (advantage, assistance) with less percentage $(15,60.0 \%),(9,36.0 \%)$ this means that these words are unfamiliar to students., while the word (agenda) with low percentage $(8,33.0 \%)$.

Table 3. Distribution of students' synonymous errors in the test of question 3

\begin{tabular}{llllllll}
\hline & & Correct & \multicolumn{3}{c}{ Incorrect } & \multicolumn{2}{c}{ Total number } \\
\cline { 3 - 8 } No. & words & Freq. & Per.\% & Freq. & Per.\% & Freq. & Per.\% \\
\hline 1 & complete & 5 & 21.0 & 20 & 80.0 & 25 & $100 \%$ \\
2 & attain & 3 & 8.0 & 23 & 92.0 & 25 & $100 \%$ \\
3 & define & 17 & 68.0 & 8 & 32.0 & 25 & $100 \%$ \\
4 & resolve & 13 & 52.0 & 12 & 48.0 & 25 & $100 \%$ \\
5 & answer & 20 & 84.0 & 4 & 16.0 & 25 & $100 \%$ \\
Total & & 11.6 & 46.40 & 13.4 & 53.60 & 50 & $100 \%$ \\
\hline
\end{tabular}

According to the students' responses in matching the synonyms that have the same meaning in question 3, which represent the use of verbs in excersise3, the above results show that the words (answer, define) are very familiar to them and have a high response with $(20,84.0 \%)$ and $(17,68.0 \%)$, while, many students fail to answer the words (complete, attain) have low percentage $(5,21.0 \%)$ and $(3,8.0 \%)$ respectively, which mean that the students failed to have a correct answer, in addition the word (resolve) has $(13,52.0 \%)$, which means that the students have a good knowledge of this word.

Table 4. Distribution of students' synonymous errors in the test of question 4

\begin{tabular}{llllllll}
\hline & & Correct & \multicolumn{3}{c}{ Incorrect } & \multicolumn{2}{c}{ Total number } \\
\cline { 3 - 7 } No. & words & Freq. & Per.\% & Freq. & Per.\% & Freq. & Per.\% \\
\hline $\mathbf{1}$ & actually & 13 & 52.0 & 12 & 48.0 & 25 & $100 \%$ \\
2 & briefly & 15 & 60.0 & 10 & 40.0 & 25 & $100 \%$ \\
3 & healthy & 13 & 52.0 & 12 & 48.0 & 25 & $100 \%$ \\
4 & loudly & 17 & 64.0 & 9 & 36.0 & 25 & $100 \%$ \\
5 & closely & 18 & 68.0 & 8 & 32.0 & 25 & $100 \%$ \\
Total & & 14.8 & 59.20 & 10.2 & 40.80 & 50 & $100 \%$ \\
\hline
\end{tabular}

The able illustrates the percentage and frequency of students' response in answering question 4, by writing the suitable synonymies which present adverb in exercise 4 . It shows that most of the students were aware of the meaning of the words (closely, loudly and briefly), which represent the frequent and percentage $(18,68.0 \%),(17$, $64.0 \%)$ and $(15,60.0 \%)$ respectively. While the students' responses in the words (actually and healthy) are low with the frequent and percentage $(13,52.0 \%)$, which indicates that they have little knowledge in the use of these words. 
Table 5. Distribution of students' synonymous errors in the test of question 5

\begin{tabular}{llllllll}
\hline & & Correct & & Incorrect & & \multicolumn{2}{c}{ Total number } \\
\cline { 3 - 7 } No. & words & Freq. & Per.\% & Freq. & Per.\% & Freq. & Per.\% \\
\hline 1 & turn, turnoff, turn around & 20 & 80.0 & 5 & 20.0 & 25 & $100 \%$ \\
2 & Broke, broke down, broke up & 17 & 68.0 & 8 & 32.0 & 25 & $100 \%$ \\
3 & Look, look after, Look up & 15 & 60.0 & 10.0 & 40.0 & 25 & $100 \%$ \\
4 & getup, get over, get on with & 10 & 40.0 & 17 & 63.0 & 25 & $100 \%$ \\
5 & Run away, run, run out of & 18 & 70.0 & 7 & 30.0 & 25 & $100 \%$ \\
Total & & 14.4 & 57.60 & 10.0 & 42.40 & 50 & $100 \%$ \\
\hline
\end{tabular}

The table result shows the percentage and frequency of the students' responses in answering question 5 by filling in the blanks with the suitable synonymies which present phrasal verbs in this exercise. The words (turn off / run and broke) with high percentage $(20,80.0 \%),(18,70.0)$ and $(17,68.0 \%)$, because they are familiar and more commonly used among ESP students, while (look after) is $(15,60.0 \%)$ with a high percentage because the word is known to the students, while the words (get on with) with low percentage $(10,40.0 \%)$, this means that this word is unfamiliar to the students and they found it difficult for them.

\subsection{Discussions}

The researcher used and designed a written test to investigate and analyses the errors committed by ESP college students in using synonyms in their correct form. The results gained from the test for all participants were analyzed and compared statistically by using frequencies and percentages.

It was found that the total correct response for question 1 was $15.8(63.20 \%)$ and the in correct response was 9.2 $(36.60 \%)$. This means that the students have a good knowledge in using the suitable synonymies that represent adjectives, while the total students' correct response in question 2 was $15.8(62.41 \%)$ while the incorrect response was $9.5(37.61 \%)$. This means that the students have a good knowledge in using the suitable synonymies that represent nouns.

It was found also that the total correct response in question 3 was $11.6(46.40 \%)$ and the in correct response was $13.4(53.60 \%)$ ). This means that the students have a good knowledge in using the suitable synonymies that represent verbs and the total correct response in question 4 was $14.8(59.20 \%)$ and the in correct response was $10.2(40.80 \%)$. This means that the students have a good knowledge in using the suitable synonymies that represent adverbs. Finally, the total correct response in question 5 was $14.4(57.60 \%)$ and the in correct response was $10.0(42.40 \%)$

The test significance indicates that there is highly difference between students' responses in using synonyms in different positions. The students' errors distributed according to correct or in correct response. Some of errors committed by the learners are due to the student's insufficient knowledge of the use of confusing words in English.

According to the result analyses we can say that the hypothesis of the study is accepted, which hypothesized that the ESP College students in the second-grade face difficulties in using synonymy.

This study is similar with (Abdalla, 2017), his study concluded that there are differences between the response of students in two colleges He recommended that EFL students should use special dictionary of synonyms. EFL learners should have great efforts to learn how to use synonyms as an integrated part in English language.

The study is compatible with (Mohammed, 2014), he found that the synonyms' errors committed by most of the students are due to their limited knowledge of English synonyms. This lack of knowledge causes a great difficulty in the choice of the correct synonyms. He reached through his recommendations that, EFL teachers should use different techniques in teaching synonyms to help them to choose the suitable synonyms.

\section{Conclusions and Recommendations}

\subsection{Conclusion}

The present study attempted to investigate the ESP college students' errors in using synonyms. The analytic results of the study showed the ESP college students of the second year in the college of Political Sciences at Al-Nahrain University are faced many difficulties in using synonyms and they committed many errors.

Some of these errors are caused by the lack knowledge of the students in acquiring synonyms and they aren't aware of the different types of these words and their usages. 
The data presented through the mentioned tables showed clearly that the ESP college students committed errors in using synonyms.

\subsection{Recommendations}

Due to the conclusion and the results of the study, the researcher recommended the followings:

1) More emphasis should be given to ESL learners in general and ESP learners in particular on applying the best strategies in teaching vocabulary.

2) Student must master vocabulary, because it is useful for them in using and understanding synonyms.

3) ESP teachers should raise awareness of the importance of synonyms for undergraduates' students.

4) ESP teachers should encourage their students to use a dictionary, so as to make use of how to find different words with their synonyms.

5) Teachers must emphasize on teaching words that have synonyms to enable learners to use them correctly.

\subsection{Findings}

From the result of the study the researcher concludes to the followings:

1) Many students are not aware of using synonyms.

2) ESP students have serious problems regarding understanding and using synonymous.

3) Teaching vocabulary play a vital role in improving students "ability in using synonymous.

\subsection{Suggestions for Further studies}

The researcher puts the following suggestions:

1) A study can be conducted on investigating grammatical error by non- native English speaker students.

2) Further studies may be taken on comparing ESL with ESP students' errors in using English Syntax.

3) English language teachers should be well trained in using various strategies and techniques in teaching English vocabulary, in order to help students to master and understand the English language system perfectly.

\section{References}

Abdalla, U. A. A. (2017). Analyzing and Evaluating EFL learners' Errors while Using Synonyms. A Case Study of Sudan University of Science and Technology. College of Graduate Studies. On line published master's thesis, Sudan University of Science and Technology College of Graduate Studies. Retrieved from http://repository.sustech.edu/handle/123456789/20825

Afghari, A., \& Khayatan, P. (2017). Collaborative Learning and Iranian EFL learners' Vocabulary Improvement through Snowball and Word-Webbing Techniques. International Journal of English Language \& Translation Studies, 5(2), 122-131.

Baumann, J. F., Kame'enui, E. J., \& Ash, G. E. (2003). Research on vocabulary instruction: Voltaire redux. In J. Flood, D. Lapp, J. R. Squire \& J. M. Jensen (Eds.), Handbook of research on teaching the English language arts (2nd ed., pp. 752-785). Mahwah, NJ: Lawrence Erlbaum Associates.

Brown, H. D. (1980). Principles of Language Learning and Teaching. New Jersey: Prentice-Hall Inc.

Cambridge Advanced Learner's Dictionary \& Thesaurus. (2019). Definition of "synonym". Cambridge University Press. Retrieved from https://dictionary.cambridge.org/dictionary/english/synonym

Cameron, L. (1994). Organizing the Word: Children's Concept and Categories, and Implications for the Teaching of English. English Language Teaching Journal, 48(1), 28-39. https://doi.org/10.1093/elt/48.1.28

Corder, S. P. (1974). Error Analysis. In J. L. P. Allen \& S. P. Corder (Eds.), Techniques in Applied Linguistics. Oxford: Oxford University Press.

Crystal, D. (1995). The Cambridge Encyclopedia of the English language. Cambridge: Cambridge University Press.

Dulay, H. C., Burt, M. K., \& Krashen, S. (1982). Language Two. New York: Oxford University Press.

Ellis, R. (1994). The study of second language acquisition. Oxford: Oxford University

Ellis, R. (1985). Understanding Second Language Acquisition. Oxford: Oxford University Press.

Enago, A. (2019). The benefit of synonyms. Retrieved from 
https://www.enago.com/academy/how-to-use-synonyms-effectively-in-a-sentence/syn

Falk, J. S. (1978). Language: and linguistics: bases for a curriculum. Prepared by ERIC Clearinghouse on Languages and Linguistics. Second Edition. New York, Toronto: John Wiley \& Sons, Inc. Canadian Modern Language Review, 35(1), 114-115. https://doi.org/10.3138/cmlr.35.1.114

Hardin, K. (2014).The Importance of Using Synonyms. Online TOEFL Preparation. Retrieved from https://magoosh.com/toefl/2014/the-importance-of-using-synonyms/

Hatch, E. M., \& Brown, C. (1995). Vocabulary, Semantics, and Language Education. English, Book, Illustrated edition. Cambridge; New York: Cambridge University Press. Retrieved from https://trove.nla.gov.au/version/38435645

Higa, M. (1963). Interference effects of intra list word relationships in verbal learning. Journal of Verbal Learning and Verbal Behavior, 2(2), 170-175. https://doi.org/10.1016/S0022-5371(63)80082-1

Kamil, M., \& Hiebert, E. (2005). Teaching and learning vocabulary: Bringing research to practice (p. 288). Mahwah, New Jersey: Lawrence Erlbaum Associates. Retrieved from http://www.erlbaum.com/

Lewis, M. (1993).The lexical approach: The state of ELT and a way forward. Hove, UK: Language Teaching Publications. Retrieved from https://lib.ugent.be/catalog/rug01:002015549

Liu, D. (2013). Salience and construal in the use of synonymy: A study of two sets of near synonymous nouns. Cognitive Linguistics, 24, 67-113. https://doi.org/10.1515/cog-2013-0003

Liu, D., \& Zhong, S. (2014). L2 vs. L1 use of synonymy: An empirical study of synonym use/acquisition. Applied Linguistics, 37(2), 239-261. https://doi.org/10.1093/applin/amu022

Lungu, I. (2003). A Linguistic Approach to Error Analysis in Teaching English as a Second Language. Ovidius University Annals of Philology, XIV, 323-328. Editura Ovidius University Press. Department of Teacher Training.

Lyons, J. (1981). Language and linguistics: An introduction. Cambridge; New York: Cambridge University Press. Retrieved from https://trove.nla.gov.au/version/45672541

Martin, M. (1984). Advanced Vocabulary Learning: The case of synonyms. Modern Language Journal, 68(2). 130-137. https://doi.org/10.1111/j.1540-4781.1984.tb01556.x

Mohammed, N. M. A. (2014). The Reasons behind the Errors Made by EFL Learners in using English Synonyms. A Case Study of the Students of the Faculty of Education Hantoub, University of Gezira, Sudan. (published doctoral dissertation). University of Khartoum, Faculty of Faculty of Education-Hantoub. Retrieved from http://repo.uofg.edu.sd/handle/123456789/1828

Normazidah, C., Koo, Y. L., \& H. A. (2012). Exploring English Language Learning and Teaching in Malaysia. GEMA Online Journal of Language Studies, 12(1), 35-55.

Read,J.(2000) Assessing Vocabulary. Cambridge: Cambridge University Press. https://doi.org/10.1017/CBO9780511732942

Reid, J. M. (1993). Teaching ESL Writing. NJ: Prentice Hall Regents.

Richards, J. C. (1974). Error Analysis: Perspectives on second language acquisition. London: Longman

Rivers, W. M., \& Nunan, D. (1991). Language teaching methodology: A textbook for teachers. Hertfordshire: Prentice Hall International.

Saville, T. M. (2006). Introducing Second Language Acquisition. Cambridge: Cambridge University Press. https://doi.org/10.1017/CBO9780511888830

Selinker, L. (1972). Inter language. In W. B. Robinett \& J. Schachter (Eds.), Second Language Learning: Contrastive Analysis, Error Analysis and Related Aspects. USA: The University of Michigan Press. https://doi.org/10.1017/S0272263100005490

Taylor, J. (1997). An Introduction to Error Analysis: The Study of Uncertainties in Physical Measurements (2nd ed.). University Science Books: Sausalito.

Webb, S. (2007). The effects of synonymy on second-language vocabulary learning. Koran Women's Junior College Japan. Reading in a Foreign Language, 19(2), 120-136. Retrieved from http://nflrc.hawaii.edu/rfl

Wilfred, F., \& Norman, L. (2015). 30 Days to a More Powerful Vocabulary. Publisher: Simon \& Schuster; Rev Ed edition (1 Oct., 1987). Retrieved from 
https://www.amazon.in/gp/product/1578660300/ref=dbs_a_def_rwt_hsch_vapi_taft_p1_i0

Yeh, Y., Liou, H., \& Li, Y. (2007). Online Synonym Materials and Concordancing for EFL College Writing. Computer Assisted Language Learning, 20(2),131-152. https://doi.org/10.1080/09588220701331451

\section{Appendix A}

\section{The Teachers' Questionnaire}

Dear Teacher,

You are kindly requested to answer the following questions as data collection for a research study entitled "Investigating and Analysis of the ESP College Students' Errors in Using Synonyms". Please.

Answer (agree, strongly agree, neutral, disagree or strongly disagree) in the right place. Add any commitments when necessary.

\begin{tabular}{|c|c|c|c|c|c|}
\hline Questions & $\begin{array}{l}\text { Strongly } \\
\text { agree }\end{array}$ & Agree & Neutral & Disagree & $\begin{array}{l}\text { Strongly } \\
\text { disagree }\end{array}$ \\
\hline \multicolumn{6}{|l|}{$\begin{array}{l}\text { 1. Hard practices in English synonyms can help students to } \\
\text { understand the concept of synonymy }\end{array}$} \\
\hline \multicolumn{6}{|l|}{$\begin{array}{l}\text { 2. Most of ESP college students are not aware of certain } \\
\text { restrictions on combinations of words }\end{array}$} \\
\hline \multicolumn{6}{|l|}{$\begin{array}{l}\text { 3. ESP college students are not aware of the different kinds of } \\
\text { synonyms }\end{array}$} \\
\hline \multicolumn{6}{|l|}{$\begin{array}{l}\text { 4. A great number of students are not aware of certain } \\
\text { restrictions on combinations of words }\end{array}$} \\
\hline \multicolumn{6}{|l|}{$\begin{array}{l}\text { 5. Most of ESP college students encounter difficulty in the } \\
\text { choice of lexical items among near synonyms }\end{array}$} \\
\hline \multicolumn{6}{|l|}{ 6. ESP college students' errors are due to the lack of their } \\
\hline \multicolumn{6}{|l|}{ knowledge in using English synonyms } \\
\hline \multirow{2}{*}{\multicolumn{6}{|c|}{$\begin{array}{l}\text { 7. Explaining the meaning of synonyms is the best technique } \\
\text { for facilitating the learning of synonyms }\end{array}$}} \\
\hline & & & & & \\
\hline \multicolumn{6}{|l|}{$\begin{array}{l}\text { 8. Teachers have to use an extensive reading strategy to make } \\
\text { vocabulary learning meaningful. }\end{array}$} \\
\hline \multicolumn{6}{|l|}{$\begin{array}{l}\text { 9. Teaching and learning synonyms through context is more } \\
\text { effective and meaningful }\end{array}$} \\
\hline $\begin{array}{l}\text { 10. ESP college students must aware of how to use the words } \\
\text { by contrasting it with its opposite. }\end{array}$ & & & & & \\
\hline
\end{tabular}

Would you like to add any suggestion or comment?

\section{Thank you for your collaboration}

\section{Appendix B}

\section{ESP College Students' Test for Second Grade}

Name of the student-

The Class

\section{Answer the following questions:}

\section{Exercise 1- Fill in the blank with the suitable synonym for each word.}
1) Bright:
2) Heavy:
3) Happy:
4) Lawful:
5) Tiny: 


\section{Exercise 2- Match the nouns that have a similar meaning.}
1) Target
a. Defect
2) Assistance
b. Goal
3) Fault
c. Help
4) Advantage
d. Schedule
5) Agenda
e. benefits

Exercise 3- Select the word that most nearly means the word provided.

1) The closest meaning to the word complete is---
a. finish
b. continue
c. start
d. wait

2) The closest meaning to the word attain is
a. suggest
b. have
c. reach
d. get

3) The closest meaning to the word define is
a. act
b. explain
c-illuminate
d. clean

4) The closest meaning to the word resolve is
a. turn
b. puzzle
c. decide
d. want

5) The closest meaning to the word answer is-------
a. reply
b. start
c. begin
d. admit

Exercise 4- Give the synonym for these words.
1) Actually
2) Briefly-
3) healthy
4) Loudly-
5) Closely

\section{Exercise 5- Fill the blanks with the suitable word.}

1) Could you the music while I'm on the phone?
a. turn
b. turn off
c. turn around

2) John his leg at the baseball game.

a. Broke

b. broke down

c. broke off

3) Would you my cat for me this weekend?
a. Look
b. look after
c. look up

4) I have to to the finish line and back.
a. run away
b. run
c. run out of
5) I don't my new science teacher
a. get up
b. get over
c. get on with

\section{Copyrights}

Copyright for this article is retained by the author, with first publication rights granted to the journal.

This is an open-access article distributed under the terms and conditions of the Creative Commons Attribution license (http://creativecommons.org/licenses/by/4.0/). 